\title{
INDUSTRIALIZAÇÃO E IMPERIALISMO NO BRASIL: da revolução de 1930 ao golpe de 1964.
}

Fabiano Godinho Faria.

(Mestrando em História pela UFF)

\begin{abstract}
Resumo: Este artigo analisa o desenvolvimento do capitalismo brasileiro sob a influencia do imperialismo e busca demarcar o período que vai da revolução de 1930 ao golpe civil militar de 1964. Examina-se o papel desempenhado pelos grupos multinacionais e de seus intelectuais orgânicos identificando, nesse processo, o papel do imperialismo Europeu e estadunidense no Brasil, tanto nas fases do corporativismo do nacional populismo como na fase do nacional desenvolvimentismo de JK
\end{abstract}

Palavras-chave: imperialismo, industrialização, desenvolvimentismo.

Abstract: This article is about the brazilian development. It has been presented since the 30 ' up to the military dictatorship in 64. It also presents the features of multinational groups and the bramehes in this proux. At first it's necessary to talk about the imperialism concepts and, after words, to look on in the brazilian history, in popular cooperative steps fron in President Juscelino Kubischeck development.

Keywords: Imperialism, industrial development, military dictatorship.

\section{INTRODUÇÃO}

O conceito de imperialismo sempre foi objeto de polêmica e estranhamento no universo acadêmico, em primeiro lugar por ser um conceito eminentemente leninista, onde a influência do capital estrangeiro, nas economias de terceiro mundo é, desde o principio, denunciada como uma forma de dominação destes por aqueles. Utilizar o conceito de imperialismo significa pressupor as contradições da economia capitalista e negar, categoricamente, o caráter positivo do investimento externo, da liberdade dos capitais, da mão invisível do mercado, da "ajuda" dos países ricos aos mais pobres. O imperialismo é um conceito irremediavelmente antiliberal, que não admite, sequer, a possibilidade de "suavização" e "relativização" que alguns acadêmicos tentam lhe dar com o pensamento de Marx ou Gramsci. Tal caráter indomável do conceito torna-o ainda mais polêmico em um tempo em que os meios de comunicação fazem coro aos investimentos externos, à 
liberalização da economia, à globalização, pregam o fim da história, entre outros mitos de fim de século e início de milênio.

Por outro lado, o imperialismo, também, é um conceito muito mal compreendido. A grande maioria dos estudantes, envolvidos nas discussões marxistas, pensa o conceito, tomando como base o imperialismo de Estado, isto é, as ações dos governos das potências capitalistas, principalmente os Estados Unidos, de pressão, ameaça e agressão aos países de terceiro mundo. Isso também é imperialismo, mas o princípio do conceito não é a ação do estado, e sim o movimento do capital internacional e transnacional sobre a economia global. Em seu tempo, Lênin observava que o quê distinguia a fase imperialista das fases anteriores do capitalismo, era o fim da concorrência entre as empresas e o domínio da economia mundial por um pequeno número de monopólios e oligopólios. Falava também da concorrência entre os imperialistas, que existia, e os obrigavam a constantes acordos, sempre provisórios, de partilha do mercado mundial.

Mas o mundo mudou, se o poder dos monopólios ainda dificulta ou impossibilita que novas empresas disputem o mercado (precisamente quando mais se fala em globalização), a disputa interimperialista entrou em nova fase quando, após o término da Segunda Guerra Mundial, os Estados Unidos conseguiram se impor como a $1^{\mathrm{a}}$ potência mundial.

O mundo em que vivemos, onde celulares com câmera são roubados por menores abandonados, e eventos em nome da paz e da tolerância, como os jogos panamericanos no Rio de Janeiro, são precedidos pela visita do caveirão, à favela é, mais do que nunca, o mundo da contradição imperialista, onde os excessos, da riqueza e da pobreza, da tecnologia e do atraso, da verdade e do cinismo, se contrapõem na mais dura dialética.

Mas, qual o papel que o imperialismo desempenhou na história do Brasil durante o século XX? E em que pode nos servir para compreender o que nos tornamos e, sobretudo, pensar o que poderíamos e o que deveríamos ser?

Após algumas voltas e tergiversações, optei por dar a este artigo o seguinte formato: primeiro, abrir uma discussão sobre conceito imperialismo, tendo por base alguns dos autores clássicos e não clássicos, que trabalham o tema e, a seguir, redesenhar um pequeno quadro do imperialismo no Brasil, desde o salto industrializante de 1930, até o 
imediato pré-golpe. Nesta análise, espero demonstrar como os movimentos e interesses do capital internacional influíram no curso que tomou a História do Brasil.

\section{SOBRE O CONCEITO DE IMPERIALISMO}

Como já é amplamente conhecido, a obra clássica sobre o tema em questão pertence a Lênin, em "Imperialismo, Fase Superior do Capitalismo". Com ela, o conceito ganha seus contornos fundamentais. O imperialismo caracterizar-se-ia como uma nova etapa do capitalismo, nascida sob a hegemonia do capital financeiro e das corporações monopolistas. Tal fenômeno englobaria as seguintes cinco características fundamentais: 1) - concentração da produção e do capital, levada a um tal grau de desenvolvimento, capaz de criar os monopólios, cujo papel é decisivo na vida econômica; 2) - fusão do capital bancário e do capital industrial e a criação, na base desse "capital financeiro", de uma oligarquia financeira; 3) - a exportação de capitais que, ao contrário da exportação de mercadorias, adquire uma importância particular; 4) - formação de uniões internacionais capitalistas monopolistas, que partilham o Mundo entre si; 5) - finalização da partilha do globo pelas maiores potências capitalistas. Para Lênin, o imperialismo é essencialmente expansionista, uma vez que o grau de concentração já atingido o obriga a tomar essa direção. Nesse sentido, está destinado (ou mesmo condenado) a reinar sobre o mundo a conquistá-lo, partilhá-lo e a repartilhá-lo

No primeiro capítulo de "O imperialismo em 1970”, Pierre Jalé (1969) cita, além do livro de Lênin, também o livro de Bukharin, como obras de referência para a construção do conceito. Jalé faz questão de frisar que a citação de Bukharin é feita à revelia do desempenho histórico do personagem. Segundo Jalé, Lênin começa por demonstrar que:

O desenvolvimento prodigioso da indústria e o processo extremamente rápido de concentração da produção em empresas cada vez maiores constituem uma das particularidades mais características do capitalismo" (Lênin 1916:17) (...) esta transformação da concorrência em monopólio é um dos fenômenos mais importantes - se não o mais importante - da economia do capitalismo atual" (LÊNIN, 1996, p.18 apud PIERRE JALÉE, 1969, p.8).

Para Lênin e Bukharin, o crescimento do capital bancário, face ao industrial, levaria os bancos, inicialmente, a "conhecer" a situação dos capitalistas isolados, depois a “controlá-los” e, finalmente, a "determinar" sua sorte. Isso se traduz na união pessoal dos 
bancos e das grandes empresas industriais e comerciais. De acordo com Lênin, o antigo capitalismo é aquele caracterizado pela existência da livre concorrência entre os capitais; o que o distingue do imperialismo é a hegemonia monopolista:

A este capital bancário - isto é - a este capital dinheiro - que na realidade, se transforma deste modo em capital industrial, dou o nome de capital financeiro. O capital financeiro é assim, o capital de que dispõem os bancos e que os industriais utilizam. (...) o ‘domínio' dos monopólios capitalistas se transforma inevitavelmente, sob o regime geral da produção mercantil e da propriedade privada, na dominação de uma oligarquia financeira" (LENIN, 1996, p.43-44).

$\mathrm{Na}$ avaliação de Lênin, na base desse processo, encontra-se o "sistema de participação", que permite comandar os negócios de uma sociedade, por ações. Em suma, a hegemonia desse capital financeiro é o que permite determinar a sorte do setor produtivo, ao mesmo tempo em que leva à falência as pequenas empresas, reservando a algumas grandes empresas o domínio de amplos setores da economia. Isso marcaria a fase imperialista da economia capitalista. Todavia, Jalée, sem discordar das análises de Lênin, pensa que o imperialismo, nos tempos modernos, apresenta características específicas, que não existiam na época clássica. De acordo com Jalée, a partir da Segunda Guerra Mundial, o capital financeiro foge aos investimentos de longo prazo e as indústrias recorrem, cada vez mais, ao autofinanciamento.

Lembrando que a taxa de autofinanciamento é a relação entre, por um lado a poupança bruta das empresas (amortizações + lucros não distribuídos) e, por outro lado, os investimentos + a variação dos estoques, A. Pietre ${ }^{1}$ indica que, mesmo para o período decorrido entre 1962 e 1964, a taxa média de autofinanciamento das empresas privadas foi de 99,3\% nos Estados Unidos, 109\% na Grã-Bretanha, 79\% na Alemanha Federal e 61\% em França. (JALÉE, 1969, p.148)

Se for verdade que as empresas recorrem, crescentemente, ao autofinanciamento, libertando-se do controle dos bancos, também o é que não são todas. Esse recurso só pode ser empregado quando a lucratividade o permite - o que exclui grande parte delas (ou seja, as empresas). De tal modo, que essa saída está cada vez mais circunscrita às empresas de caráter monopolista. Algumas delas, exatamente por esse caráter, já não podem ser facilmente designadas financeiras ou industriais, dado que alguns

\footnotetext{
1 Revue Politique et Parlamentaire, Dezembro de 1967; Problèmes economiques, $\mathrm{n}^{\circ} 1060,25$ de abril de1968, apud Jalée,1969, op cit.
} 
capitalistas industriais compram seus próprios bancos. Segundo Jalée, não se pode mais falar de um predomínio do capital financeiro sobre o produtivo, mas de uma interpenetração, no sentido de uma fusão, da formação, não de uma oligarquia financeira, (uma elite caracterizada por sua atividade financiadora, exterior à produção, constituída pelos grandes bancos), mas de uma oligarquia financeira e industrial, ou seja, de investidores capitalistas que atuam em diversos setores da economia, exercendo, tanto atividades ligadas à produção, como também atuando no mercado financeiro. É o que se chama de expansão horizontal, quando, por exemplo, um grande holding empresarial reúne empresas comerciais, bancárias e produtivas. Nesses casos, o domínio do capital bancário sobre o produtivo ou não existe, ou deve ser relativisado, já que, em última instância, faz parte de uma mesma rede:

\begin{abstract}
Nos Estados Unidos, impedidas pelas leis antitrustes de se concentrarem no seu domínio de origem, as grandes empresas encaminharam-se para uma diversificação que não encontra obstáculos. Atualmente, mais de $70 \%$ das fusões americanas são do tipo conglomerado. (...)Um certo número de holdings percorre o caminho inverso do outrora descrito por Lênin, ou seja, um grupo industrial dedicar-se a atividades bancárias (JALÉE, 1969, p155).

E mais adiante:

E no fim das contas, da mesma forma que nos pareceu ter hoje em dia perdido o significado a oposição entre exportações de capitais e exportações de mercadorias devido às estreitas ligações entre umas e outras, também nos parece que a oposição, e mesmo a distinção entre capital financeiro e capital industrial se tornam um pouco supérfluas. A noção de oligarquia financeira deve ser substituída agora pela de oligarquia financeira e industrial (JALÉE,1969,161).
\end{abstract}

Lênin já havia percebido o papel desempenhado pelos capitais oriundos dos países avançados - em que o desenvolvimento do capitalismo monopolista e financeiro resulta num enorme excedente de capitais. Entretanto, desenvolvimento desigual do capitalismo (que é uma das leis do capital na procura da maximização do lucro), esses capitais excedentes não são investidos nos seus países de origem. De acordo com Bukharin, a razão principal da migração do capital é a procura de uma composição orgânica do capital mais favorável ao seu processo de acumulação.

Quanto mais desenvolvido é um país, mais baixa a taxa de lucro e mais intensa a 'reprodução' do capital, tanto mais violento é o processo de eliminação. E, inversamente, quanto mais elevada é a taxa de lucro, mais fraca a composição orgânica do capital e mais forte a procura do capital, tanto mais viva é a força de atração (LÊNIN, 1996, p. 37). 
“A exportação de capitais para o estrangeiro se torna (...) um meio de encorajar exportações de mercadorias" (LÊNIN, 1996, p.59), dificultadas pelo protecionismo aduaneiro. Bukharin acrescenta que, a tendência a expatriar-se, desempenha também a função de produzir-se, localmente, substitutos de certas exportações entravadas e também: "a exportação do capital cria, além do mais, condições favoráveis para a indústria do país de origem desse capital" (LÊNIN, 1996, p. 97). Em suma, para Lênin,

O capital financeiro estende (...) a sua rede sobre todos os países do mundo" e "os países exportadores de capitais repartiram, em sentido figurado, o mundo" (Lênin 1916:61) Paralelamente à partilha econômica do mundo entre associações capitalistas: "Estabelecem-se certas relações entre associações políticas, entre estados, baseadas na partilha territorial do mundo, na luta pelas colônias, na luta pelo território econômico. (LÊNIN, 1996, p.68).

No seu tempo, Lênin pôde observar que:

O capital financeiro e a política internacional tendente à partilha econômica e política do mundo aos estados diferentes formas transitórias de dependência" visa aqui "as diversas formas de países dependentes, que nominalmente gozam de independência política, mas que, na realidade, ficam presos nas malhas de uma dependência financeira e diplomática. (LÊNIN, 1996, p.77).

No entanto, Lênin afirmava que, tais partilhas, eram apenas provisórias e que a disputa entre as potências imperialistas tendia a tornar necessárias novas divisões, de acordo com a correlação de força entre tais países. Em análises mais contemporâneas, não podemos perder de vista que, dada à hegemonia do imperialismo estadunidense, o peso dessa disputa interimperialista deve ser relativizado.

\section{INDUSTRIALIZAÇÃO E PENETRAÇÃO DO CAPITAL MONOPOLISTA NO TERCEIRO MUNDO}

Muitos autores marxistas acentuaram a importância dos países dependentes como escoadouros para as mercadorias dos países industrializados. Ao verificarem, porém, a importância das transferências de lucro, são levados, hoje, a pôr o problema ao inverso.

A grande lucratividade dos países imperialistas, nos paises de terceiro mundo, está na qualidade deste comércio. Este fator tem permitido, aos países de primeiro mundo, supervalorizarem sua produção. A troca desigual significa trocar uma pequena quantidade de trabalho, altamente remunerada, por uma grande quantidade de trabalho de baixa remuneração. Assim, os países capitalistas compensam uma taxa de mais-valia, 
sensivelmente menor, em seu território, com uma sobre-exploração de mais-valia no terceiro mundo. Além de assegurar harmonia social e até certa cooperação da classe trabalhadora para o projeto imperialista, em seus países, a sobrevalorização da produção tem o efeito adicional de atenuar a baixa tendência da taxa de lucro e acentuá-la nos países subdesenvolvidos. E, desse modo, o imperialismo empurra os efeitos mais perversos das contradições do capitalismo para a sua "periferia".2

Esta baixa remuneração da força de trabalho, que reproduz as desigualdades no terceiro mundo, ao mesmo tempo garante conforto e bem estar aos países capitalistas avançados. Isso significa transferência de trabalho dos países dependentes, diretamente para os países imperialistas, às custas das formas extremas de exploração da força de trabalho. Por essa via, o terceiro mundo acumulou, até o final da década de 80, um déficit crescente, em sua balança comercial, a qual ameaça colapsar a economia capitalista. Foi para evitar ou adiar essa crise, que os capitalistas injetaram uma grande quantidade de capital nas economias dos países subdesenvolvidos. Essa "ajuda", porem, sempre foi insuficiente. $\mathrm{O}$ objetivo foi, em primeiro lugar, manter os mecanismos da troca desigual. Jalée estima que o déficit comercial médio, a cada ano, nos países subdesenvolvidos, girava em torno de 19\%, em sua época, ou seja, os países imperialistas, ao mesmo tempo em que injetam recursos, com uma mão, a fim de assegurar o funcionamento mínimo da economia do terceiro mundo, com outra mão, arrancam superávits comerciais. Não raro, esse superávit é facilitado por meio de regras favoráveis ao capital imperialista, obtidas por meio de coações extra-econômicas, possibilitadas pelos compromissos regulatórios que esses países subdesenvolvidos têm de assumir para fazerem jus ao dinheiro obtido, geralmente sob a forma de empréstimos.

\section{INDUSTRIALIZAÇÃO E LIBERALISMO NO BRASIL}

Dentre os países da América Latina, Brasil, Argentina e México conseguiram alcançar um considerável desenvolvimento industrial. No Brasil, esse processo se iniciou

\footnotetext{
2 O termo periferia aqui é meramente instrumental, os países de terceiro mundo não são "periferia" dos países de primeiro mundo, num sentido de regiões em estágios mais atrasados do capitalismo, mas sim, parte fundamental da engrenagem capitalista global, não existiriam países ricos sem países pobres a sustentá-los mediante a troca desigual, não existe o centro e a periferia, existe o todo.
} 
com a chamada Revolução de 1930 e foi marcado pela busca de um modelo alternativo, para a exportação cafeeira, hegemônica, desde o período imperial. Segundo Vianna (1978), durante os anos vinte, a burguesia industrial brasileira possuía realmente uma ideologia liberal, razão pela qual foi radicalmente contra as regulamentações do estado oligárquico. Por essa época, esse setor da classe dominante era pouco ativo politicamente.

O empresariado brasileiro, até 1926, pouco afeito à política, enxergava o mundo pelas lentes das fábricas. A ortodoxia liberal, mantida pelo Estado, controlado pelas elites agrárias, lhe parecia satisfatória: assim poderia exercer formas selvagens de exploração do trabalho, sem sofrer ameaças das classes subalternas. Por isso, não seria racional exigir que ele (o empresariado) formulasse políticas que visassem ameaçar ou derrubar o poder da elite agrária. A plena realização do individuo competitivo era sua meta. A única intervenção que esperava, por parte do Estado, era a repressão ao movimento sindical. As formas não liberais de dominação, que diminuíam ou negavam este indivíduo, tais como o corporativismo e o fascismo, lhe eram estranhas, uma vez que, no ideário liberal clássico, a intervenção do Estado deve ser a menor possível. Essa consciência liberal está na origem da feroz resistência do empresariado às primeiras iniciativas de leis trabalhistas, ensaiadas pelo Estado brasileiro, a partir de 1926 (férias, código de menores, caixas previdenciárias etc.). Contra essas iniciativas, vai fazer uso da ideologia liberal, sob o argumento de que estas medidas incentivam o vício, a licenciosidade, a criminalidade, além de causar imensos prejuízos às fábricas. Nesta conjuntura, emergem as primeiras divergências entre os empresários e as elites agrárias, o empresariado vai argumentar que a legislação trabalhista só atinge os trabalhadores da indústria, e que, portanto, os industriais iriam arcar sozinhos com os custos da regulamentação do trabalho.

Contudo, o liberalismo da República Velha não resistiu à emergência do movimento operário e às contestações da classe média, como o caso do Tenentismo. Nessa época, o poder político se achava em mãos das oligarquias cafeeiras, de São Paulo e Minas Gerais. Face à crise de 1929 e o grande número de falências que a ela se seguiu (os cafeicultores paulistas estiveram entre as maiores vítimas), esta fração da classe dominante buscou manter seu poder político, rompendo o pacto conhecido como "a república do cafécom-leite". Contudo, em um contexto de profunda crise econômica, o conjunto das frações dominantes não aceitava mais o domínio dos cafeicultores paulistas. Contra a hegemonia 
da elite agrária, exportadora, levantam-se, então, as elites agrárias, voltadas para o mercado interno, sustentadas, politicamente, nos estados do RS, RJ, BA e MG, pela classe média e mesmo por setores organizados da classe trabalhadora, movimento que levou Getúlio Vargas ao poder.

Aqui é importante pontuar sobre o caminho adotado pelo Brasil para a industrialização. Nesse particular, descartamos a via americana (sustentada no dinamismo capitalista da pequena propriedade agrícola), a via revolucionária (caso francês e inglês) e optamos por uma via parecida com a "via prussiana". No caso brasileiro, a diferença está no fato de que a direção do processo não se deu via setor dominante das elites agrárias e sim pelo seu setor mais fraco. Exatamente por isso, vai ter de abrigar, em sua proposta política, os interesses das outras frações dominantes, menores, como é o caso dos industriais. É preciso, no entanto, distinguir as necessidades econômicas de classe dos agentes envolvidos, da própria visão que estes faziam do processo. Os industriais paulistas, entranhados de uma ideologia ultraliberal, não vão reconhecer, na nova elite no poder, seus melhores aliados e vão lutar ao lado da elite agrária - exportadora, em 1932, por um estado à moda da República Velha: ortodoxamente liberal.

Derrotados no movimento de 1932, os industriais não demoraram muito tempo para perceber que o populismo e corporativismo de Getúlio Vargas, formas políticas distantes do liberalismo, longe de prejudicar seus interesses, os reforçaram, especialmente devido ao controle sobre o movimento operário e pelo caráter parcial do Estado que, em praticamente todas as ocasiões de conflito, tendeu para o interesse dos industriais.

O Estado (1930-1937) se caracterizará por concurso de frações dominantes em que, nenhuma delas, deterá a hegemonia. Os cafeicultores, até então dominantes, foram depostos, embora continuassem com relativo poder de barganha. A elite agrária, voltada ao mercado interno, embora tivesse apoiado entusiasticamente o movimento de 1930, estava dividida em frações regionais, sem um programa que abarcasse seu conjunto. Os industriais, tradicionais aliados da elite cafeeira, ainda constituíam um setor minoritário da economia e, de forma geral, não possuíam experiência de atuação política. Nesse contexto, Vargas conseguiu consolidar-se, como um árbitro, entre as frações dominantes, estabelecendo um Estado autonomizado no político, que acabou por levar adiante um 
projeto de modernização industrial, sob pressupostos contrários à afirmação do indivíduo e à ideologia liberal da burguesia industrial, sua maior beneficiária.

A mudança de posição ideológica do bloco, no poder, anteriormente ultraliberal, pode ser mensurada no engajamento da fração burguesa industria,l na formação dos sindicatos patronais, dentro do espírito corporativista, que iria assumir a política sindical, a partir daquela conjuntura. Nos momentos em que o movimento operário comportava-se mais combativamente, maior era a proporção de sindicatos patronais que procuravam a mediação do Estado, no conflito, e maior a proporção de sindicatos de trabalhadores que tentavam afastar-se da estrutura sindical oficial corporativista. Longe do Estado se constituir num arbitro entre as classes, tanto os empresários como o movimento dos trabalhadores percebiam claramente sua parcialidade.

Segundo Mendonça (1986), existem quatro correntes historiográficas, principais, em relação à Revolução de 1930. 1) - a que identifica uma hegemonia do setor industrial; 2) - a que admite a hegemonia das classes médias; 3) a identifica o concurso entre latifundiários e industriais; 4) - a que se preocupa com seus agentes diretos. Filiamo-nos a esta última corrente, uma vez que, como já mencionado, nenhuma das frações dominantes detinha a hegemonia do processo, de modo que a política desenvolvimentista de Vargas deve ser compreendida, principalmente, a partir de uma política do Estado para a sociedade e não como expressão da vontade organizada de classes e frações de classes organizadas.

No decurso dos anos vinte, as reivindicações dos industriais podem ser elencadas em três frentes básicas: 1) - a luta pela participação efetiva no aparelho de estado; 2) - a construção de um discurso que a valorizasse; c) - a construção de um programa de industrialização.

Isso apontava na seguinte direção: 1) - superação, via indústria, do grau de vulnerabilidade externa da economia; 2) - a condenação da política de exportação de bens primários como sustentáculo da economia brasileira; 3 ) - o estabelecimento da identidade: industrialização - grandeza nacional; 4) - a convocação da intervenção do Estado como forma de viabilização da infra-estrutura.

Essas reivindicações situam-se no marco de uma tentativa de tornar nacionais os interesses de classe, ou seja, de convencer o edifício social de que seus projetos 
econômicos não eram simplesmente a expressão do desejo de uma classe social, mas sim os interesses de toda a sociedade. Assim, tentavam conquistar a hegemonia.

Entretanto, devido à consolidada hegemonia do setor cafeeiro, somente a partir do estado populista e corporativista, é que suas demandas vão adquirir dimensão de interesse nacional.

O movimento de 1930 foi heterogêneo no que tange a sua composição (setores agrários, industriais e médios e uma pequena participação da classe trabalhadora). No Brasil, em face à crise capitalista de 1929, os preços do café caíram interna e internacionalmente. Todavia, como a indústria ainda dava seus primeiros passos, o Estado Brasileiro precisou contar com a receita das exportações agrícolas (principalmente do setor cafeeiro) e ainda criar regras que beneficiassem os industriais, em detrimento de outros setores. A este caráter paradoxal da industrialização brasileira, Mendonça (1986) criou o conceito de "industrialização restringida."

Não é demais dizer que a industrialização, no Brasil, beneficiou-se de relações de trabalho, arcaicas, para diminuir seus custos de produção e mesmo da reprodução da força de trabalho, o que lhe rendeu altos patamares de extração de mais-valia. Ao mesmo tempo, a intervenção do Estado garantiu que o valor dos salários não ocorresse mediante a negociação capital e trabalho, ou seja, que o valor da força de trabalho não fosse regulada pelo mercado e sim decretada pelo executivo. Ao fixar seu valor em termos realmente biológicos $^{3}$, as empresas tiveram sua folha de pagamento reduzida. Os empresários reconheceram a forma autoritária da legislação corporativista, mas não aceitaram seu caráter corporativo em todas as suas dimensões. Vários pontos da legislação trabalhista (como a estabilidade, indenização por demissão sem justa causa e férias) eram impunemente desrespeitados. Quando o assunto era despesa com direitos sociais, retornavam a seus argumentos liberais. Aos trabalhadores, restava pagar o imposto sindical, com o qual o Estado transformava sua representação de classe em um de seus sustentáculos do poder.

\footnotetext{
${ }^{3} \mathrm{O}$ conceito de salário biológico refere-se ao tipo de remuneração do trabalho calculada para possibilitar simplesmente a reprodução biológica do trabalhador e sua família. Para saber mais sobre o caráter biológico do salário na era Vargas ler: Francisco de Oliveira (2004) e Luiz Werneck Vianna (1978), utilizado como fonte bibliográfica para este trabalho.
} 
O Estado financiou o desenvolvimento industrial e garantiu a lucratividade do setor. No decênio 1929-1939, a indústria cresceu a uma média anual de 8,5\% contra 2,2\% da agricultura. Tal fato deveu-se a toda uma orientação do Estado, que favoreceu a primeira, em detrimento da segunda. A industrialização era o pilar central do "projeto de nação" que se construía, enquanto ideologia, para neutralizar tensões latentes. Os conflitos entre o setor agrário e o industrial tiveram solução no âmbito da maquina estatal.

Desse modo, a opção por um desenvolvimento industrial, calcado em capitais nacionais, não foi uma escolha, mas o único caminho possível. Os investimentos externos eram quase inexistentes, em decorrência, em primeiro lugar, da crise de 1929; em segundo, da Guerra Mundial e, em terceiro, da reconstrução dos países aliados (Inglaterra e França) e mesmo dos ex-inimigos, como por exemplo, a Alemanha.

Evidentemente, que o governo brasileiro ressaltava, a todo o momento, o seu caráter "nacionalista". A definição do que seria "nação" e "interesse nacional", era objeto de constante disputa entre o Estado (corporativo) e os industriais. Estes defendiam uma política estatal, voltada para o controle do movimento dos trabalhadores, típica da atitude corporativista, mas discordavam do viés social deste mesmo corporativismo, na medida em que combatiam as medidas sociais do pacto social.

Dois fatores, entretanto, pesaram para a queda do Estado Novo: a pressão externa, liderada pelos Estados Unidos (contrário ao desenvolvimento industrial brasileiro, especialmente sob bases nacionalistas e corporativistas) e a pressão interna, principalmente de interesses agrários e importadores. O fim do Estado Novo deixou margem de manobra para que PSD e PTB fossem a "força maior da redemocratização". À UDN, criada na oposição a Vargas, restava apenas um discurso ultra-moralizante, ultra-liberal e ultragolpista. A massa, quando entrou em cena, foi para eleger os candidatos da herança varguista.

O populismo de Vargas, empenhado no desenvolvimento autônomo e na recusa do capital externo, voltou, em 1951, sustentado em três fatores: emprego, consumo e participação eleitoral. Mas, apesar da criação da PETROBRAS e do BNDES, o pacto populista, sustentado na industrialização restringida, entrou em crise.O principal fator foi a contradição de um modelo de industrialização, dependente da receita obtida pelas exportações do setor agrário. 
A Era Vargas marcou a história brasileira pelo seu caráter modernizante e ao mesmo tempo conservador, na medida em que o avanço industrial não veio acompanhado de uma maior distribuição da renda nacional. Muito pelo contrário; a indústria brasileira compensou seu atraso tecnológico com uma extrema exploração do trabalho. Superado o efeito desnorteador da crise de 1929, que permitiu a Vargas colocar-se entre as classes sociais. E, com o fim da Segunda Guerra Mundial, as velhas oligarquias e os agora influentes industriais uniram-se na defesa de uma nova ordem social, prescindiam do Estado corporativista e ansiavam por uma formação de Estado em que pudessem influir diretamente e sem intermediações no aparato estatal. O governo de Eurico Gaspar Dutra personificou esse intento e o segundo governo de Vargas esteve longe de ter a força coesionadora que os seus primeiros quinze anos representaram.

Com Juscelino Kubischeck, o ciclo de desenvolvimento nacional entra em nova fase, influenciado diretamente pela elite industrial e pelo capital internacional.

\section{O NACIONAL DESENVOLVIMENTISMO DE JK}

O ciclo de desenvolvimento da era Vargas gerou uma grande acumulação e concentração de renda, que possibilitou o grande salto industrializante dos anos JK. Com o fim da reconstrução européia, Japão e comunidade européia estavam interessados em investir no terceiro mundo, ou seja, havia uma pressão para que o terceiro mundo se abrisse aos capitais estrangeiros.

Desta vez, o salto industrial se deu sob o setor III (automóveis e eletrodomésticos). As facilidades criadas pelo Estado para o capital estrangeiro foram tão grandes que obrigaram ao capital nacional a associar-se a ele para desfrutar dos mesmos benefícios fiscais, tais como isenções e subsídios. Como o governo não estava disposto a cobrar imposto sobre os ganhos industriais, recorreu à emissão de moeda para gerar receita e criar uma poupança forçada, não sem alguma inflação.

O esforço industrializante foi sustentado sobre o tripé: capital nacional, capital estrangeiro, capital estatal. O rápido crescimento do setor industrial obrigou o Estado a ampliar o investimento em infra-estrutura. O programa de Metas, sob o governo JK, unificou capitais privados e públicos, sob a direção do Estado e alicerçado na ideologia 
desenvolvimentista. Os objetivos do Plano de Metas podem ser resumidos em dois níveis: 1) - no curto prazo, acelerar o processo de acumulação capitalista; 2) - no médio prazo, elevar o nível de vida da população, com a abertura de novas vagas de emprego. Face a esses objetivos, quatro setores-chave foram privilegiados: energia, transportes, alimentação e indústrias de base. - política que favoreceu, amplamente, a entrada do capital estrangeiro, com o aumento da intervenção do setor público, na formação interna de capitais e no esforço para canalizar recursos privados para áreas estratégicas, como forma de estabilizar as taxas de inflação.

O governo JK estava apoiado, no legislativo, pela aliança PSD-PTB. Essa coligação era sustentada da forma tradicional: apoio em troca de favores. Ao PSD, coube a direção da SUDENE; ao PTB as pastas da educação e do trabalho, além de apoio à sua atividade sindical. A principal oposição era feita pela UDN. Apesar de sua maioria parlamentar, o governo se empenhou em diminuir o poder do legislativo, criando instâncias de decisão paralelas, tais como os "grupos de trabalho", compostos por técnicos e membros chaves das administrações públicas e os "grupos executivos", criados por decreto, para aprovar pontos do Plano de Metas. Nestas instancias de decisões paralelas, percebe-se claramente a influência do capital nacional e internacional que, sob pretensos argumentos técnicos, definiam, de acordo com seus interesses de classe, as diretrizes econômicas do País.

Durante o governo JK a implementação do Plano de Metas foi exitosa. Do ponto de vista quantitativo, foi um período que deu grandes saltos no ramo industrial, mas também trouxe algumas contradições: 1) - ampliação da dependência da economia brasileira ao capital externo; 2) - aumento da inflação e da dívida externa, fruto da política fiscal de extremo benefício ao capital estrangeiro, que levou o Estado a sustentar o desenvolvimento, à custa da emissão do papel-moeda e endividamento externo; 3) - o padrão de desenvolvimento industrial, tendo por base grandes capitais, vedou o crescimento de pequenas empresas nacionais, incapazes de concorrerem com as multinacionais; 4) - descompasso na integração dos três setores industriais: o setor de indústria estatal não conseguiu crescer na mesma velocidade que o multinacional, tornando-se atrofiado em relação a este; 5) - o setor dirigido ao consumo popular (têxteis, vestuário, alimentação, etc.) sofreu com a queda do poder de compra dos salários e 
estagnou-se; Em suma, instaurou-se uma conflituosa relação entre uma industrialização voltada para o mercado interno e o fato de sua propriedade pertencer ao capital estrangeiro, para o qual se dirigiam seus lucros, em desfavorecimento da acumulação nacional.

Operou-se, nesse período, uma inversão em relação ao modelo anterior. Tratouse, na verdade da instauração Centro/Periferia, que só fez aumentar a dependência externa brasileira. Este ciclo de industrialização gerou uma profunda concentração de renda, que abalou o pacto populista com a entrada em cena do movimento social organizado. Para adiar este acontecimento, o governo investiu em duas frentes: favoreceu acordos salariais com a cúpula sindicalista, ligada ao PCB e, principalmente, ao PTB, e investiu na consolidação de uma ideologia nacional desenvolvimentista.

Diferente do discurso varguista, o nacional desenvolvimentismo de JK enfatizava mais o desenvolvimento nacional do que a soberania. Tal discurso ocultava alguns percalços negativos, como a crescente dependência externa, o progressivo aumento dos poderes do executivo e o crescente papel político desempenhado pelos empresários, os quais se envolveriam, diretamente, no golpe de 64, para derrubar o Estado populista.

O principal fomentador da ideologia populista foi o Instituto Superior de Estudos Brasileiros (ISEB). O pensamento isebiano pautava-se em dois pontos marcantes: 1) -.uma visão dualista da sociedade brasileira; 2) - a eleição da burguesia nacional como vanguarda do desenvolvimento brasileiro. Seu segmento mais moderado, integrado principalmente, por Hélio Jaguaribe e Candido Mendes, era de uma visão instrumental do nacionalismo. Para esses intelectuais, o capital estrangeiro poderia protagonizar, sem problemas, o desenvolvimento econômico brasileiro, desde que o fizesse no interesse nacional. Já a ala radical do ISEB, representada por Nelson Werneck Sodré e Vieira Pinto, era contrária à entrada de capitais estrangeiros, principalmente em áreas estratégicas do interesse nacional. Mas, apesar das grandes diferenças internas, o ISEB era favorável a uma ideologia desenvolvimentista, que apontasse diretrizes para o desenvolvimento, o qual, apoiando-se nos setores mais modernos e dinâmicos da economia, iria superar os resquícios do atraso, representado, sobretudo, pelos privilégios das ordens agrárias tradicionais.

O desdobramento de todo esse projeto seria a "revolução" brasileira, quando a extinção do subdesenvolvimento colocaria o Brasil em novo papel na sociedade internacional, na condição de país desenvolvido. Essa ideologia teve forte impacto na 
sociedade brasileira. Mesmo a vanguarda operária, em muitos momentos, substituiu o discurso da luta de classes pelo do desenvolvimento nacional (como será abordado mais adiante). A essa atitude, associada à estrutura sindical corporativista, JK deveu muito de sua governabilidade. Além da cooperação ideológica dos sindicalistas, a classe trabalhadora, nessa época, viveu intensas transformações: a absorção veloz de mão de obra, migrada do campo, mudou o perfil do operariado urbano - composto, majoritariamente, por uma mão de obra jovem, sem tradição de lutas e mesmo de experiência de vida urbana. Esse aspecto, por outro lado (num contexto de crescimento econômico), dificultava o trabalho das lideranças mais combativas.

A elite industrial, maior beneficiária do salto industrializante, se organizava cada vez mais enquanto classe. O projeto industrial para o país pode ser resumido na seguinte fórmula: capital estrangeiro, mais iniciativa privada nacional, mais controle estatal dos recursos básicos, sem nenhuma competição entre os três. Neste sentido, as bases do modelo da internacionalização eram assumidas pela burguesia que - ao contrário das visões produzidas por certos segmentos sobre ela - jamais defendeu a industrialização autônoma (MENDONÇA, 1986, p.66).

A elite industrial atuava em duas frentes: uma oficial, para conter, via políticas de estado, as reivindicações trabalhistas e outra paralela, como nos já mencionados "grupos de trabalho" e "grupos executivos", onde os intelectuais orgânicos, ligados ao capital nacional e internacional, estabeleciam as orientações estratégicas da economia nacional, livres da interferência do legislativo e sob a proteção do executivo, e também em seus fóruns e associações próprios, tais como o Instituto de Pesquisas Econômicas e Sociais (IPES), a Escola Superior de Guerra (ESG), além da tradicional Federação das Indústrias de São Paulo (FIESP), etc, para pressionar e influenciar as políticas de Estado, a partir da sociedade civil.

De acordo com Dreifuss, "O capitalismo brasileiro viria a ser tanto transnacional quanto oligopolista e subordinado aos centros de expansão capitalista" (DREIFUSS,1981, p. 49). A penetração, no Brasil, de um bloco multinacional de poder, liderado por interesses estadunidenses, trouxe novas relações econômicas e políticas, tais como: a crescente concentração econômica, a centralização do capital e o controle oligopolista.

A superioridade tecnológica e financeira do capital estrangeiro foi seu maior trunfo, uma vez que, fortalecido pela política de abertura econômica, o capital nacional já 
não podia competir com ele, de modo que, a associação subordinada, era uma questão de sobrevivência. Segundo Dreifuss

\begin{abstract}
Contrariamente ao modelo de investimento dos Estados Unidos em muitos outros países latinoamericanos, as ações americanas em companhias de utilidade pública e companhias de mineração no Brasil eram relativamente poucas em relação ao investimento americanos na produção de maquinário, automotores e utilidades domésticas. A maior parte dos investimentos no Brasil era feita por corporações americanas multinacionais de maior importância, organizadas localmente de acordo com a lei brasileira de modo a usufruir vantagens administrativas e tributárias.em alguns casos essas eram organizadas sob um nome tal que não as ligava, à primeira vista, à matriz, a fim de ganhar identidade local (DREIFUSS,1981, p. 57).
\end{abstract}

De acordo com o autor, em nota ao final do capítulo, essa era uma recomendação do Departamento de Estado Estadunidense para o comportamento das multinacionais em alguns países. "O processo de concentração industrial foi acompanhado por uma extrema concentração da posse da terra" (DREIFUSS,1981,p.60). O processo de controle multinacional, sob a economia brasileira, deu-se, principalmente, através da formação de holdings transnacionais, "organizações financeiras que mantinham e geriam as ações e operações de um certo grupo de empresas" (DREIFUSS,1981,p.60). Entre os grupos nacionais, havia um grande número de empresas familiares ou multifamiliares. $\mathrm{O}$ controle dessas empresas pelo capital transnacional dava-se também pelo controle acionário das holdings.

\footnotetext{
Nenhuma formação é mais representativa do processo de integração capitalista (internacionalização, centralização organizacional e fusão e interpenetração financeiroindustrial) que ocorria em meados da década de cinqüenta e princípios da década de sessenta que a do gigantesco Atlantic Community Developement Group for Latin America, mais conhecida por sua sigla ADELA. A ADELA foi formada em 1962 a partir de recomendações feitas por um Think-thank encabeçado pelo vice presidente da Standart Oil of New Jersey (grupo Rockefeller) e pelo vice presidente da FIAT (complexo Agneli). A ADELA foi posta em ação por parlamentares da OTAN e senadores dos Estados Unidos, entre os quais exerceram papel importante Hubert Horatio Humprhrey e Jacob Javits, então senadores e membros do Council for foreign relations. A ADELA foi registrada no Grão - Ducado de Luxemburgo em setembro de 1964, operando na América latina através de um escritório em Lima no Peru (DREIFUSS, 1981, p.61).
}

Várias empresas ligadas à ADELA estiveram na linha de frente de mobilização que derrubou Jango. O capital monopolista, mediado pelas corporações transnacionais, desempenhava um papel estratégico, junto à economia brasileira, determinando o ritmo e a direção da industrialização no Brasil. Não por acaso a tendência para a concentração em grandes unidades produtivas se consolidou no período posterior a 1964. As principais 
decisões nas empresas multinacionais e mesmo em algumas empresas nacionais (cujo controle acionário estava sob o poder de holdings internacionais) eram tomadas no exterior. Um certo "relatório do Senado Americano salientou que as corporações multinacionais conduziam-se como um determinante crítico da performance econômica brasileira" (DREIFUSS,1981, p.65).

E mais adiante afirma o autor:

O mero peso econômico de interesses multinacionais na economia brasileira tornou-se um fator político Central no final da década de cinqüenta. A fim de impelir seus interesses específicos, o capital transnacional apoiou-se não somente em seu poder econômico, mas também desenvolveu perícia organizacional e capacidade política próprias para influenciar as diretrizes políticas no Brasil (...) os intelectuais orgânicos do bloco oligopolista que não tinham liderança política, pois essa estava nas mãos de interesses populistas, e excluídos da representação associativa pela convergência de classe no poder, tentariam contornar os canais políticos e administrativos tradicionais de articulação e agregação de demandas (DREIFUSS,1981, p. 66).

No início dos anos 60, este setor já se achava suficientemente forte para apoiar o fim do pacto populista e impor o seu projeto de classe. Segundo Mendonça (1986), nesse momento, a burguesia se destacava como o setor mais privilegiado no pacto populista e a crise iniciada em 1962 inviabilizava o atendimento às demandas populares. Entretanto, o regime não resistia às suas próprias contradições, particularmente com a chegada de uma fase descendente do ciclo de desenvolvimento capitalista.

O Estado não poderia continuar financiando o desenvolvimento produtivo, a menos que lançasse mão de dois expedientes: emitir papel moeda e gerar inflação ou recorrer ao endividamento externo e gerar dependência econômica. Ambas as soluções eram desaconselháveis ao pacto populista. Outros fatores, porém, agravaram a crise: o investimento externo passou a evitar o País por causa do risco da instabilidade política, os preços da produção agrícola (a qual fora relegada no plano dos investimentos) subiram, encarecendo o custo de reprodução da mão de obra ${ }^{4}$.

As forças armadas, que até então tinham uma "neutralidade benevolente", em relação às greves, mudaram violentamente de posição com a "greve dos sargentos", que

\footnotetext{
${ }^{4}$ A instabilidade política a que me refiro, começa em começa em 25 de agosto de 1961, com a renuncia de Jânio Quadros e vai até 31 de março de 1964, com o golpe civil militar que depôs João Goulart, devido ao enorme aumento da demanda por alimentos em função do crescimento populacional das cidades, os produtos agrícolas aumentaram de preço substancialmente, encarecendo o custo da reprodução da mão de obra e diminuindo o consumo interno da produção industrial, os presidentes da ditadura militar conseguiram contornar estes problemas graças a acentuada política de arrocho salarial, para uma discussão detalhada sobre a crise econômica do período em questão ler: Vianna (1978) e Oliveira (2004).
} 
afetou a disciplina militar. O discurso populista de João Goulart, em torno das reformas de base, assustou as camadas proprietárias que, preocupadas com a sua posição social, alinharam-se à Direita e apoiaram o golpe de 1964, o qual correspondeu a um realinhamento do bloco no poder, onde empresários e militares se uniram em torno de instituições, tais como o IPES, o IBAD e a ESG, e prescindiram do Estado Populista, para legitimar sua dominação.

Nesta conjuntura, as maiores polêmicas se davam em torno da política externa e das reformas de base. Numa aproximação com o movimento popular, Jango acena com uma política externa independente e com as reformas de base e as divergências políticas ganham dimensões cada vez mais dramáticas.

Para Maria do Carmo Campello de Souza

A divisão se delineava no interior dos partidos conservadores. No PSD, o grupo da Ala Moça apoiava as reformas enquanto seus outros segmentos retiravam o apoio a Jango. Na UDN, as diferenças eram entre o grupo progressista da Bossa Nova e os conservadores ortodoxos. Quanto ao PTB, ampliava-se sua penetração no interior enquanto os pequenos partidos ideológicos cresciam em influencia nos grandes centros urbanos. Tudo apontava na direção de um realinhamento partidário (SOUZA, 1976, 139-40).

Ainda de acordo com a autora, nesse contexto ganharam força os Estados maiores do golpe de 64: o IPES, a ESG e sua DSN, e o IBAD. A aliança IPES/IBAD fazia alardes na campanha contra o que lhe parecia a bolchevização do País. Suas principais denúncias eram: 1) - que obstáculos ao capital internacional significariam uma brecha para restrições mais amplas a qualquer capital; 2) - que as manifestações populares desorganizavam a produção e, no limite, subvertiam a ordem e até mesmo a hierarquia militar.

Paralelamente, o movimento social radicalizava-se. $\mathrm{O}$ processo de industrialização agrícola, que ganhara força, na década de 1950, acelerou a expulsão de grande contingente rural que, tão logo chegava à cidade, deparava-se com a queda dos salários propiciada, entre outras coisas, pelo aumento da demanda de emprego. Nas cidades, o "sindicalismo político" colocava em pauta os grandes temas nacionais. No campo, as Ligas Camponesas organizavam os trabalhadores rurais e tentavam resgatar (ou conquistar) direitos civis e legais, assumindo seu caráter nitidamente sindical. 


\section{O PCB NESSE CONTEXTO}

Desde a denúncia dos crimes de Stalin, em 1956, durante o XX congresso do Partido Comunista da União Soviética (PUCS), quando o então secretário Geral Nikita Krushev revelou os bastidores do terror stalinista (assassinatos, torturas, perseguição política etc), o PCB vivia uma profunda crise interna, agravada ainda por varias posições políticas, assumidas publicamente, em divergência às resoluções de seu IV Congresso, realizado em 1948, sob o impacto da legalidade cassada, no ano anterior. No sentido de apontar uma saída para esta crise, uma comissão composta de vários dirigentes, intelectuais do partido, se reuniu secretamente entre no final de 1957 e fevereiro de 1958, redigindo um documento que viria a ser conhecido como a declaração política, em março de 1958, cujo conteúdo mantinha os princípios fundamentais no V Congresso, em 1960. Segundo a nova orientação política, a revolução brasileira era concebida enquanto um processo a ser realizado em duas etapas: a primeira, democrática; a segunda, socialista. De acordo com Jacob Gorender

\footnotetext{
Assim, a primeira etapa em curso seria a da revolução nacional e democrática, de conteúdo antiimperialista e antifeudal. Após a vitória dela é que se passaria a segunda etapa - a da revolução socialista. (...) A tarefa dos comunistas devia ser a de lutar pelas reformas de estrutura $^{5}$ a fim de que o desenvolvimento capitalista viesse a tomar um curso que o aproximaria da revolução nacional e democrática. (...) O bom caminho devia ser o caminho pacífico da revolução (GORENDER, 2003, p. 33-34).
}

No início da década de 1960, o PCB experimentou um considerável aumento da sua influência em todos os setores do cenário nacional, chegando mesmo a influenciar políticas governamentais. Isso o levou a considerar que a "revolução brasileira" caminhava num processo continuo e democrático - a democracia lhe parecia um fato consolidado, a burguesia nacional era vista como progressista e democrática e os grandes inimigos seriam o imperialismo e os resquícios feudais de alguns setores dos latifundiários e da burguesia internacional, os quais deveriam ser combatidos por uma frente ampla, que englobasse a burguesia nacional, a pequena burguesia, os setores progressistas dos latifundiários, das forças armadas, operários e camponeses.

\footnotetext{
${ }^{5}$ Ou reformas de base, como viriam a se tornar conhecidas.
} 
Esta frente deveria empenhar-se nas necessárias reformas de base (reforma agrária, a reforma urbana, a distribuição de renda, a nacionalização do sistema financeiro entre outras medidas). A idéia de um golpe da Direita parecia impossível à direção do PCB, dado o caráter democrático da burguesia nacional e das forças armadas, tidas então como guardiãs da legalidade. Contudo, para surpresa de muitos comunistas, no dia 31 de março de 1964, grupos liderados pelo PSD, UDN e setores das forças armadas organizaram uma coalizão que iria depor o então presidente da república João Goulart. As luzes da democracia se apagavam, e não se tornariam a acender, por mais de vinte anos.

\section{CONCLUSÃO}

Em sua industrialização, o Brasil se beneficiou de um momento conturbado da conjuntura mundial: Primeira Guerra Mundial - que demandou, de alguns países até então agrícolas, alguma produção industrial, principalmente têxtil. Crise de 29 - que favoreceu a busca de um modelo alternativo, ao agrário exportador, com gerência do Estado sobre a Economia. E Segunda Guerra Mundial - que aprofundou o processo de industrialização, iniciado com a primeira. Essas circunstâncias possibilitaram ao Brasil, ainda que no bloco dos países capitalistas pobres, desempenhar um papel qualitativamente diferente dentro da divisão internacional do trabalho.

Na direção política do processo de industrialização, estava, não uma classe, mas um consórcio de classes, o que favoreceu a figura de Vargas, possibilitando-o, em certa medida, a autonomizar-se e impor-se sobre esse consórcio, através do pacto corporativista.

O modelo de industrialização, iniciado por Vargas, sustentou-se, quase exclusivamente, em capitais nacionais e priorizou o estabelecimento de matrizes de longo prazo para a industrialização, tais como as estatais metalúrgicas e energéticas. Este foi, reconhecidamente, um período de grande transformação, no Brasil, apesar do intenso autoritarismo, o qual, diga-se de passagem, não era nenhuma novidade para aqueles que viveram a República Velha nas pequenas cidades do interior e depois migraram para o centro, durante a Era Vargas. 
Com o fim de Segunda Guerra Mundial, e avançada a reconstrução européia e do Japão, os capitais monopolistas voltam-se para o terceiro mundo. No caso do Brasil, organizados em "estados maiores", buscam assumir o controle do processo de industrialização, ocasião em que se observa a viragem do modelo Vargas para o modelo JK.

A burguesia nacional jamais foi nacionalista e muito menos anti-imperialista. como queria o PCB. Em nenhum momento da industrialização brasileira, a burguesia nacional apresentou divergências estratégicas com o capital monopolista internacional. Aliás, mesmo a industrialização da Era Vargas, sustentada em capitais nacionais, jamais representou qualquer independência face ao capital monopolista, que continuou beneficiando-se da "troca desigual" com o Brasil, e manteve, de long, a dianteira tecnológica.

O período JK corresponde a um momento mais agressivo do capital monopolista, manifesto na grande quantidade de investimentos externos (especialmente estadunidenses) e na pressão exercida por seus intelectuais orgânicos para que se adequasse ao Estado conforme seus interesses. Beneficiado, ao longo de três décadas, pela política de cooptação da classe trabalhadora, efetuada pelo populismo, os capitais nacionais e internacionais já queriam caminhar sem ele, na década de 1960. Por isso, mobilizaram-se, contra Jango, herdeiro do varguismo.

Para uma parte considerável do movimento de esquerda, naquele tempo da guerra fria, o conceito de imperialismo não era algo muito definido. Para grande parte da militância, o imperialismo era quase a mesma coisa que Estados Unidos - que eram os inimigos da URSS. Por isso, não era tão difícil aceitar que o "capital nacional" era revolucionário, como dizia Prestes.

Graças a sua proximidade com Jango, e sua grande simpatia nos meios urbanos, o PCB podia esperar um belo futuro parlamentar se conseguisse, novamente ,a legalidade. A julgar pela suas resoluções e declarações, tal partido não representava risco ao capital nacional e nem mesmo ao capital monopolista a ele associado. Entretanto, os intelectuais orgânicos do capital multinacional - em tempos de guerra fria não pensavam assim e não lhe fizeram qualquer concessão. 
Uma vez que o golpe fora insistentemente desacreditado pelo PCB, à época hegemônico, na Esquerda, nada de relevante se pôde fazer, na última hora. O capital financeiro saudou, em todo o mundo, a "revolução democrática brasileira".

\section{REFERÊNCIA BIBLIOGRÁFICA}

AMIN, Samir. O imperialismo, passado e presente. Tempo, vol. 9, n. 18, jan-jun 2005, 7 Letras/Eduff, 2005.

CHESNAIS, François (Coord.). A mundialização financeira: gênese, custos e riscos. São Paulo: Xamã, 1998.

DREIFUSS, René Armand. 1964: a conquista do estado: ação política poder e golpe de classe. 3. ed., Petrópolis: Vozes, 1981.

GORENDER, Jacob. Combate nas trevas. São Paulo: Ática, 1998.

JALEE, Pierre. O imperialismo em 1970. Lisboa: Livraria Sá da Costa, 1969.

LENIN, Vladimir Ilichi Ulianof. Imperialismo, fase superior do capitalismo, Niterói RJ, Diálogo, 1996.

MENDONÇA, Sônia Regina de. Estado e economia no Brasil: opções de desenvolvimento. Rio de Janeiro: Graal, 1986.

MENDONÇA, Sônia Regina de; FONTES, Virginia Maria, História do Brasil recente: 1964-1992. Série Princípios, 4. ed., São Paulo: Ática, 2004.

OLIVEIRA, Francisco de. Crítica a razão dualista: ornitorrinco. São Paulo: Boitempo, 2004.

SOUZA, Maria do Carmo Campello de. Estado e partidos políticos no Brasil. São Paulo, Alfa e Omega, 1976.

VIANNA, Luiz Werneck. Liberalismo e sindicato no Brasil. 2. ed., São Paulo: Paz e Terra, 1978. 